UDC $550.3+581.1$

\title{
LABORATORY TESTS ABOUT RESISTIVITY VARIATION IN SOIL, IN CONNECTION WITH ROOT PRESENCE
}

\author{
(c) 2021 г. Y. Giambastiani ${ }^{1,4,5}$, E. Guastini ${ }^{2}$, F. Preti ${ }^{2,5}$, G. Censini $^{3}$ \\ ${ }^{1}$ CNR-IBE, Institute of Bioeconomy, National Research Council, Florence, Italy \\ ${ }^{2}$ DAGRI, Department of Science and Technology of Agriculture, Food, \\ Environment and Forestry, University of Florence, Florence, Italy \\ ${ }^{3}$ GEORISORSE ITALIA SAS, Siena, Italy \\ ${ }^{4}$ Bluebiloba Startup Innovativa SRL, Florence, Italy \\ ${ }^{5}$ FORTECH - DAGRI Joint Laboratory - Innovative technologies for the sustainable forestry management, \\ Florence, Italy \\ Corresponding author: Y. Giambastiani (e-mail: giambastiani@lamma.toscana.it)
}

\begin{abstract}
Knowledge about root system distribution plays an important role in slope stability studies, as this factor grants an increase in soil geotechnical properties (cohesion and angle of friction) and determines a different underground water circulation. Published studies about in situ application of Electrical Resistivity Tomography analysis show how the root presence affects the measurable soil resistivity values, confirming the suitability to investigate the application of such technique, aiming to estimate root density in soil with an indirect and non-invasive method.

This study, laboratory-based and led on reconstructed samples in controlled condition, aims to find a correlation between the resistivity variations and the various factors that can affect them (humidity, bulk density, presence of foreign bodies).

The tests involved a clay-loam soil taken from Quaracchi (Florence, Italy), in an experimental fir-wood (Picea abies) owned by the Scuola di Agraria of Università degli Studi di Firenze, the first-chosen site for field applications of Electrical Resistivity Tomography. The soil has been dried out in a lab stove, sieved at $2 \mathrm{~mm}$, and then placed in a Lexan box $(30 \times 20 \times 20 \mathrm{~cm})$, without compaction.

Inside the sample have been inserted 3 series of 4 iron electrodes, at three different depths. Resistivity measures are conducted on the three levels using a Syscal R2 with electrodes connected in a Wenner configuration. Root presence is simulated inserting 48 bamboo sticks (simple geometry, replicable root density). The tests were repeated in time, monitoring the natural variations in humidity (evapotranspiration) and bulk density (compaction).

The first results show an increase in resistivity with the decrease in mean soil humidity and increase in bulk density. Root presence, on equal terms, entails higher soil resistivity values whose trend appears, on first impression, to be fixed in an exponential law in relation to humidity.
\end{abstract}

Keywords: root density, geophysics, water content, indirect detection, electrical survey.

\section{Introduction}

Slope stability is influenced by the presence of plants, both herbaceous and arboreal [Preti, Petrone, 2013]. To evaluate the protective function of plants, within the hydrogeological risk, it is therefore appropriate to evaluate the architecture of the root systems of plants [González-Ollauri, Mickovski, 2015], in order to study the specific effect of a single tree, of arboreal species, and hopefully of a forest stand, in ensuring adequate stability on the slope [Chirico et al., 2013].

To qualitatively evaluate the hypogeal organs of a plant, an estimate can be made by observing the upper portion. Quantitative assessment appears to be a study that necessarily requires higher costs, in terms of time and work [Schwarz, Cohen, Or, 2010]. To measure, weigh and evaluate distribution, depth, etc. of the root system of an arboreal plant, it is 
necessary tocarry out an excavation, which allows the exposing of these organs [Bischetti et $a l ., 2009]$. The excavation often causes irreversible damage to the roots, with consequent risks for the epigeal portion. These methods are definable as direct and destructive.

Published studies [Amato et al., 2008, 2010; Rossi et al., 2011] confirm the suitability of Electrical Resistivity Tomography (ERT) analysis for estimation of root density in soil with an indirect and non-invasive method [Cassiani et al., 2012]. Analysis shows how the root presence affects the soil resistivity values. The aim of this study, laboratory-based and led on reconstructed samples in controlled condition, is to find a correlation between the resistivity variations and some factors that can affect them (humidity, bulk density, presence of foreign bodies, temperature), in particular the presence of roots of plants. The electrical surveys find numerous applications for subsoil analysis, water flow analysis, study of the bedrock, presence of fossil fuel accumulations, studies regarding permafrost and seismic risk [Kaznacheev et al., 2020; Lebedeva et al., 2019; Simakov et al., 2020; Skvortsova et al., 2016; Tiapkin et al., 2019; Isaev, Kotov, Sergeev, 2020]. Electrical surveys, like ERT, can be used for in situ soil mapping and monitoring, assessing the flow of the electric current, and then determining a soil characterization [Pozdnyakov, Pozdnyakova, 2002].

This work concerns the influence of roots on the resistivity of vegetated soil [Zenone et $a l ., 2008]$. The found correlation can allow quantitative analyses on the distribution of roots in the soil [Amato et al., 2008], therefore the quantification of the space explored, the development over time of the roots with time-lapse investigations [Mary et al., 2018], contributing significantly to the understanding of slope stability and individual trees.

With this study, we try to understand how the presence of roots influences the soil resistivity, in order to develop a field methodology, through which it is possible to carry out analyses on tree root systems in an indirect way. The technique chosen for this purpose is the electrical sounding survey. This technique measures how the electric current spreads in a medium [Kulikov, Kaminsky, Yakovlev, 2017; Samouëlian et al., 2005]. The basic assumptions are that the presence of woody material in the soil leads to greater resistivity, given the poor conductivity of this material.

The novelty of this study, compared with the cited works, concerns the understanding of the behavior of the woody material towards resistance, if this variation occurs because of the evapotranspiration mechanisms of the plants, or if the presence of the roots implies a variation, given the insulating characteristics of the wood.

\section{Materials and methods}

With this study, resistivity measurements were carried out with the geoelectrical method. The used instrument is Syscal R2 [Batayneh, Al-Diabat, 2002]. The applied device follows the Wenner array configuration system, visible in Fig. 1 [Morris, Moreno, Sagues, 1996]. The transmission characteristics, for the carried out analysis, were: voltage: 12 volts and typical current was $\sim 1.25$ to 0.625 amps.

The analyses were carried out with different soils, coming from different sites: clayeysilty alluvial urban soil (sand $41 \%$, silt $27 \%$, clay $32 \%$ ), soil of calcareous origin with extensive rocky outcrops (sand $59 \%$, silt $38 \%$, clay $3 \%$ ), soil of arenaceous origin with scarce rocky outcrops (sand $50 \%$, silt $30 \%$, clay $20 \%$ ). The tests were performed by measuring the resistivity of the soil in different humidity conditions, adding water to the sample, and with the presence in the sample of different materials (stones and roots). Resistivity measurements were carried out with constant monitoring of humidity and soil density. Portions of roots were taken from a spruce uprooted for other purpose. 


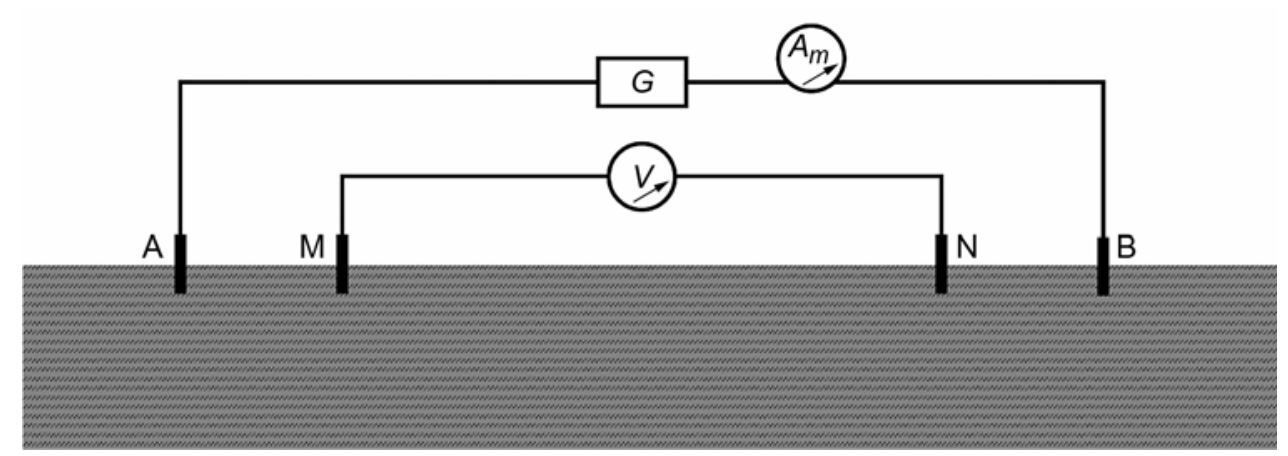

Fig. 1. Diagram explaining the principle of Electrical Resistivity Tomography. A, B - current electrodes, $\mathrm{M}, \mathrm{N}$ - potential electrodes, $G$ - current generator, $A_{m}$ - ammeter, $V$ - voltmeter

Рис. 1. Схема, поясняющая принцип электротомографии. А, В - излучающие электроды; $\mathrm{M}, \mathrm{N}$ измерительные электроды, $G$ - источник тока, $A_{m}$ - амперметр, $V$ - вольтметр

\section{Equipment}

The study was carried out using the geoelectric sounding survey technique performed with Syscal R2, Iris instrument. An electric current is sent into the soil through a pair of electrodes (current electrodes). A voltmeter, connected to a pair of receiving electrodes, allows to measure the potential difference and therefore the apparent electrical resistivity of the soil, multiplying the potential current drop sent by a geometric coefficient, depending on the disposition of the electrodes on the ground [Okpoli, 2013]. The equation used for this was [Herman, 2001]:

$$
R_{\mathrm{a}}=2 \pi a \Delta V / I
$$

where, $R_{\mathrm{a}}$ is the apparent resistivity in ohm $\cdot \mathrm{m} ; 2 \pi a$ is the geometric factor depending on electrodes spacing $a(5 \mathrm{~cm}) ; \Delta V$ is the potential difference (volt) and $I$ is the total current (amp).

During the varying of humidity in time, in the investigated sample, we observe a change in soil resistivity, furthermore the testes are repeated adding the bamboo sticks and changing soil density. Through the analysis of spatial resistivity gradients, it is possible to identify inhomogeneities (bodies with different electrical conduction capacities) present in the investigated soil, in the form of distortion of the normal distribution of the electric potential.

\section{Preliminary tests with PVC pipes}

The first laboratory tests (Fig. 2), performed by reconstructing the samples in construction pipes (PVC, diameter $20 \mathrm{~cm}$ ) using material as it is taken from three different areas, were carried out for the three types of soil, varying the content of water, the presence of roots and the degree of compaction. Holes in the wall of the tubes were provided to insert the electrodes with an interval of $5 \mathrm{~cm}$ and measure the resistivity at 4 heights.

The ground was inserted into the pipe without any original structure modification. The soil samples for the preliminary tests were collected in 3 different locations: the urban soil in

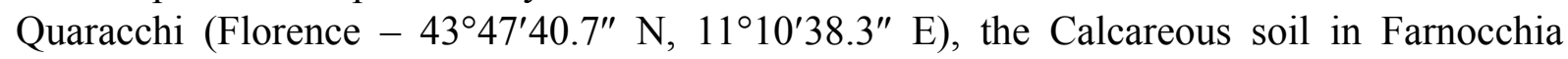
(Lucca $-43^{\circ} 58^{\prime} 56.3^{\prime \prime} \mathrm{N}, 10^{\circ} 17^{\prime} 52.6^{\prime \prime} \mathrm{E}$ ) and the soil of arenaceous origin in Pomezzana (Lucca $\left.-43^{\circ} 59^{\prime} 15.8^{\prime \prime} \mathrm{N}, 10^{\circ} 18^{\prime} 53.7^{\prime \prime} \mathrm{E}\right)$. During these tests, the density and moisture of the soil were not measured analytically, but we made changes between one test and another, simply by compacting the soil inside the pipe and adding water. The roots were placed inside the tube, before inserting the earth. 


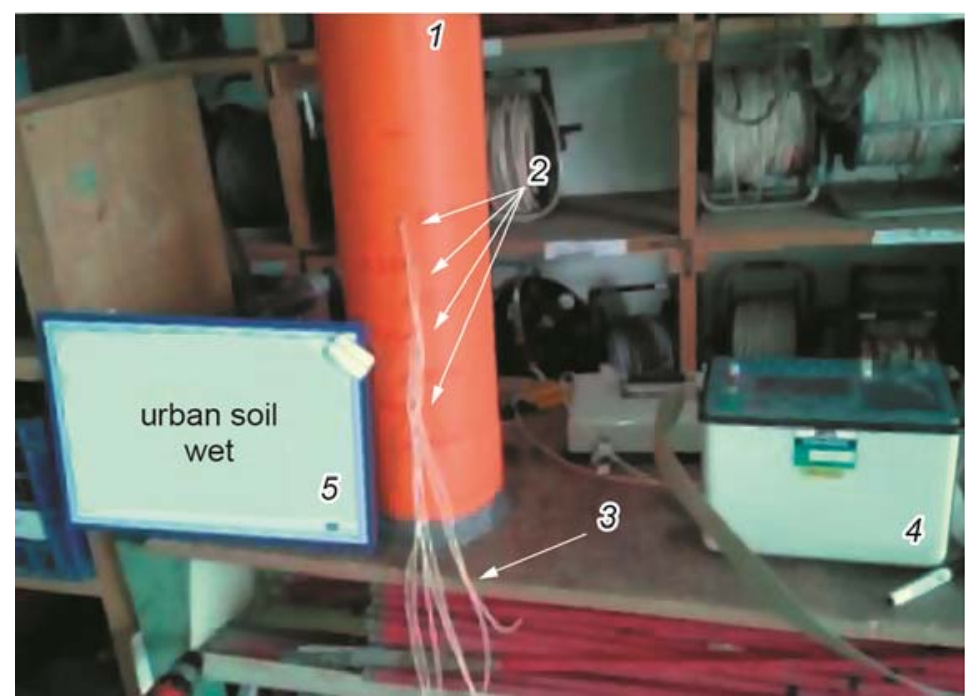

Fig. 2. Preliminary tests, general view of the laboratory setup. 1 - container for soil samples (plastic pipe); 2 - four bolts-electrodes installed on the surface of the pipe at a distance of $5 \mathrm{~cm}$ from each other; 3 - copper connecting cables; 4 - Syscal R2 equipment; 5 - a plate with information about the measured values and types of soil

Рис. 2. Предварительные испытания, общий вид лабораторной установки. 1 - контейнер для образцов почвы (пластиковая труба); 2 - четыре болта-электрода, установленные на поверхности трубы на расстоянии 5 см друг от друга; 3 - медные соединительные кабели; 4 - аппаратура Syscal R2; 5 - табличка с информацией об измеряемых значениях и типах грунта

\section{Main test with Lexan box}

Subsequently, in the geotechnical laboratory of DAGRI, a Lexan box (Fig. 3, on the left) was created (dimensions $30 \times 20 \times 20 \mathrm{~cm}$ ) to conduct further tests in density and humidity controlled conditions on sample homogeneity.
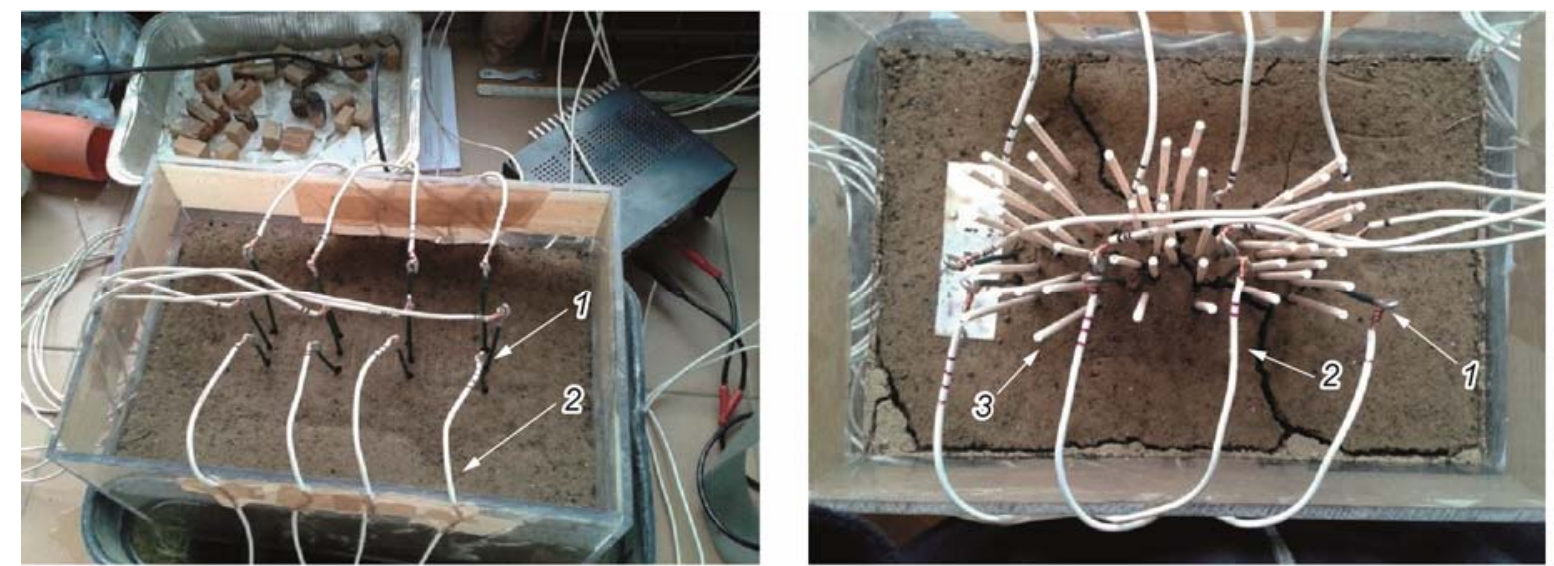

Fig. 3. Main tests, start (on the left) and end (on the right) of the measurement cycle in the Lexan box $30 \times 20 \times 20 \mathrm{~cm}$ in size. 1 - electrodes (thin iron rods in an insulating sheath); 2 - connecting cables; 3 bamboo sticks

Рис. 3. Основные испытания, начало (слева) и конец (справа) цикла измерений в лексановом контейнере размером $30 \times 20 \times 20 \mathrm{~cm}$. 1 - электроды (тонкие железные стержни в изолирующей оболочке); 2 - соединительные кабели; 3 - бамбуковые палочки 
The test consists in measuring the resistivity of the soil at 3 different depths, at $2 \mathrm{~cm}$, $6.5 \mathrm{~cm}$ and $13 \mathrm{~cm}$ (see Fig. 3). Root presence is simulated with the insert of $1 \mathrm{~mm}$ diameter bamboo sticks (see Fig. 3, on the right). The soil, dried in the stove and crushed to eliminate agglomerates, is inserted into the box without compacting it. The bamboo sticks permit a simple calculation of root area ratio (RAR), a parameter that describes the root density in a known area. RAR is the ratio between the sum of root sections and the rooted area [Giambastiani et al., 2017]. Placing a real root in the Lexan box and then filling it with soil, would have led to problems, like empty spaces formation. Furthermore, a cutted root or a bamboo sticks have the same behavior on evapotranspiration. A quantity of water equal to $50 \%$ of the weight of the soil is added. Then three rows of four iron electrodes are inserted, insulated up to the measurement depth. The first measurements were carried out on the soil inserted in the box without compaction, adding water initially and measuring during drying. Adding 48 bamboo sticks and the same amount of water made the second series of measurements. After the second drying, the soil was mixed and compacted in order to obtain a higher density, and then the measurements were repeated during drying and with the bamboo sticks. The first test (incompact without bamboo sticks) was terminated when the last measurement performed was the same as the previous one (this was considered an outlay and not reported in the analysis). For the two cases with bamboo sticks, the tests were terminated until resistivity was unmeasurable (excessive drying and cracks formation).

\section{Results}

From the first preliminary tests carried out with PVC pipes, a different behavior of the soil resistivity is found based on the soil conditions and the presence of roots. The minimum resistivity values are found with moist soil (groundwater or drinking water is a good current conductor, in relation to dry soil), when soil is inserted into the PVC pipe with a higher density (compared to adding without compaction) the resistivity values are always less than in the dry case. The resistivity values of the rooted soil are always higher than in the other cases. For the three sites, we find different resistivity scales based on the chemical and physical nature of the soil (Fig. 4).
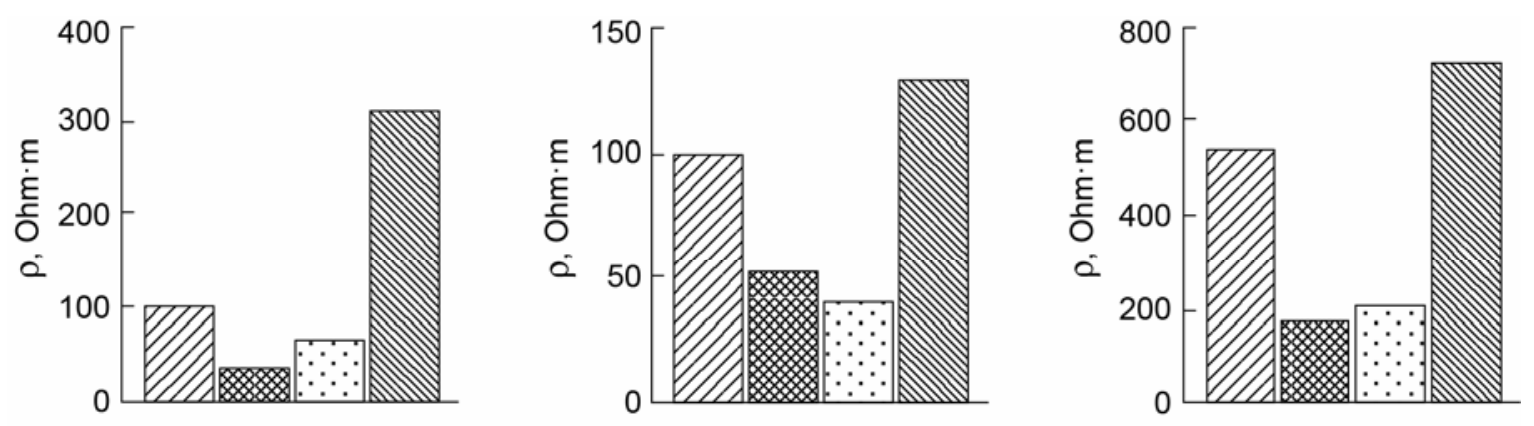

\section{$\bigotimes 1 \otimes 2 \quad \cdot 3 \quad \mathbb{Q} 4$}

Fig. 4. Preliminary measurements in the plastic pipe. Resistivity values $(\rho, \mathrm{Ohm} \cdot \mathrm{m})$ for different types of soil: urban (on the left), calcareous (center), arenaria (on the right). 1-4 - soil conditions: dry (1), wet (2), compacted (3), soil with roots (4)

Рис. 4. Предварительные измерения в пластиковой трубе. Значения удельного сопротивления $(\rho$, Ом·м) для разных типов почвы: городской (слева), известковой (по центру), песчаной (справа). 1-4 - состояния почвы: сухая (1), влажная (2), уплотненная (3), почва с корнями (4) 
The resistivity values measured for the three different types of soils are comparable with the data in the literature, in particular author [Reynolds, 1997] reports that calcareous soils (limestone) can have a resistivity range between 300 and $10.000 \mathrm{ohm} \cdot \mathrm{m}$, the origin arenaceous soil (sandstone) between 200 and $5000 \mathrm{ohm} \cdot \mathrm{m}$. Urban soil, net of anthropogenic disturbances, can be associated with an alluvial soil, with a resistivity range between 50-1000 ohm·m [Reynolds, 1997].

Subsequent tests with the Lexan box show how the insertion of wooden elements into the soil, of a size comparable to plant roots, significantly affects the resistivity of the soil (Fig. 5), with high $R$-squared and $p$-value always $<0.01$. Fig. 6 shows all the values measured at the three different depths, from what the graphs show, the average is well representative of the trends. The three series of resistivity measurements carried out during the drying cycle are well correlated with soil moisture, but show different trends with respect to the presence of wooden elements and soil density.

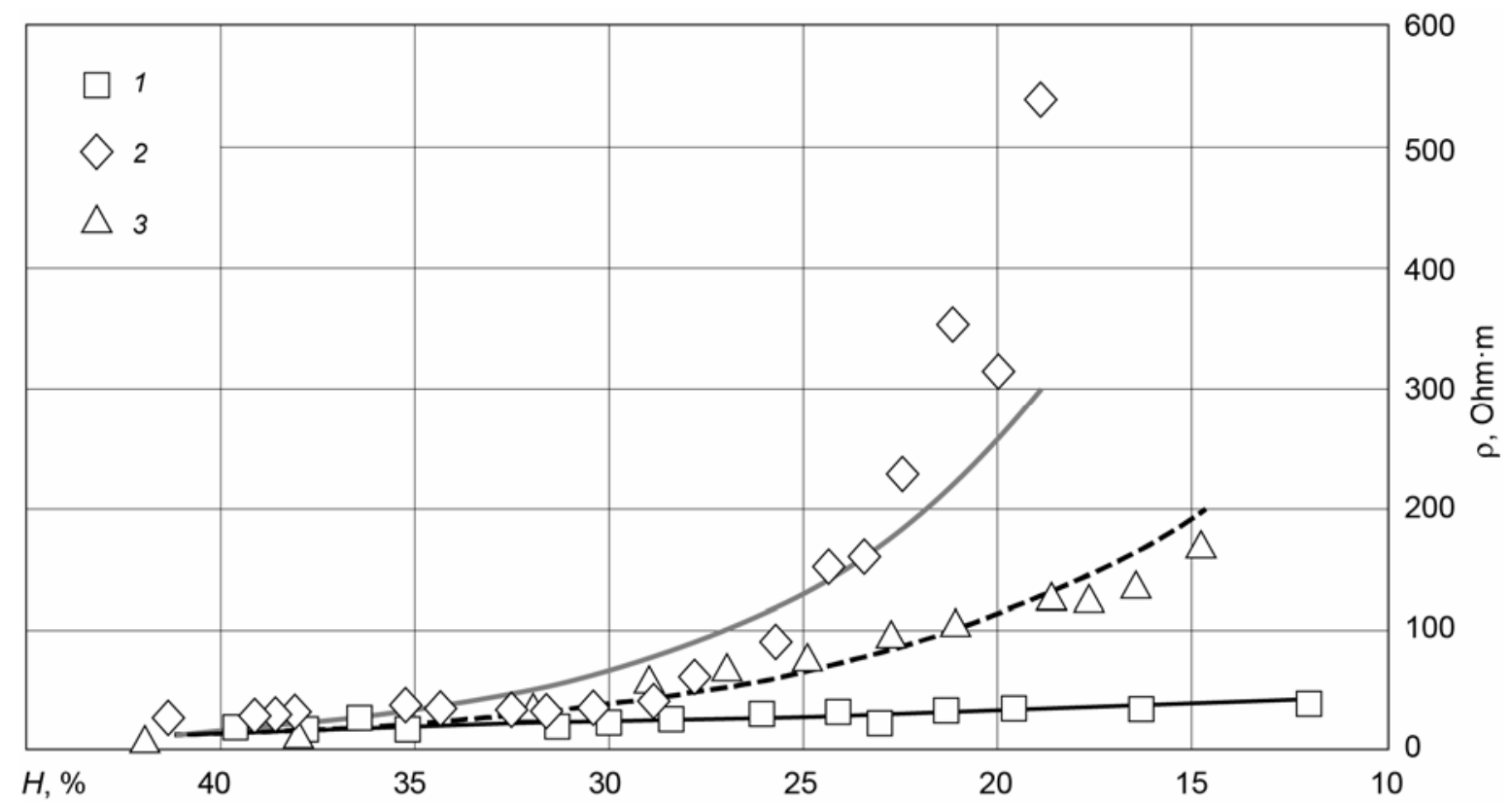

Fig. 5. Main tests in the Lexan box. Dependence of resistivity $(\rho, \mathrm{Ohm} \cdot \mathrm{m})$ on humidity $(H, \%)$ in the process of soil drying. Each mark displays the average value of measurements at three depths: $2 \mathrm{~cm}$ (1), $6.5 \mathrm{~cm}(2), 13 \mathrm{~cm} \mathrm{(3);} \rho$ corresponds to the apparent resistivity $R_{a}$, calculated by the formula (1). The gray line is the approximating curve described by the equation $y=3795.4 e^{-0.134 x}$ (determination coefficient $R^{2}=0.8558, p$-level of the significance $p$-value $=1.471 \cdot 10^{-8}$ ) for uncompacted soil; dashed line is the approximating curve $y=941.73 e^{-0.106 x}\left(R^{2}=0.9574\right.$, $p$-value $\left.=1.083 \cdot 10^{-5}\right)$ for the soil with bamboo sticks; black line is the approximating curve, $y=62.868 e^{-0.031 x}\left(R^{2}=0.8394, p\right.$-value $\left.=3.478 \cdot 10^{-8}\right)$ for compacted soil

Рис. 5. Основные испытания в лексановом контейнере. Зависимость удельного сопротивления $(\rho$, Ом·м) от влажности $(H, \%)$ в процессе высыхания почвы. Каждый значок отображает среднее значение измерений на трех глубинах: 2 см (1), 6.5 см (2), 13 см (3); $\rho$ соответствует кажущемуся удельному сопротивлению $R_{a}$, рассчитанному по формуле (1). Серая линия - аппроксимирующая кривая, описываемая уравнением $y=3795.4 e^{-0.134 x}$ (коэффициент детерминации $R^{2}=0.8558, p$-уровень значимости $p$-value $=1.471 \cdot 10^{-8}$ ) для неуплотненной почвы; штриховая линия - аппроксимирующая кривая $y=941.73 e^{-0.106 x}\left(R^{2}=0.9574, p\right.$-value $\left.=1.083 \cdot 10^{-5}\right)$ для почвы с бамбуковыми палочками; черная линия - аппроксимирующая кривая, $y=62.868 e^{-0.031 x}$ $\left(R^{2}=0.8394, p\right.$-value $\left.=3.478 \cdot 10^{-8}\right)$ для уплотненной почвы 

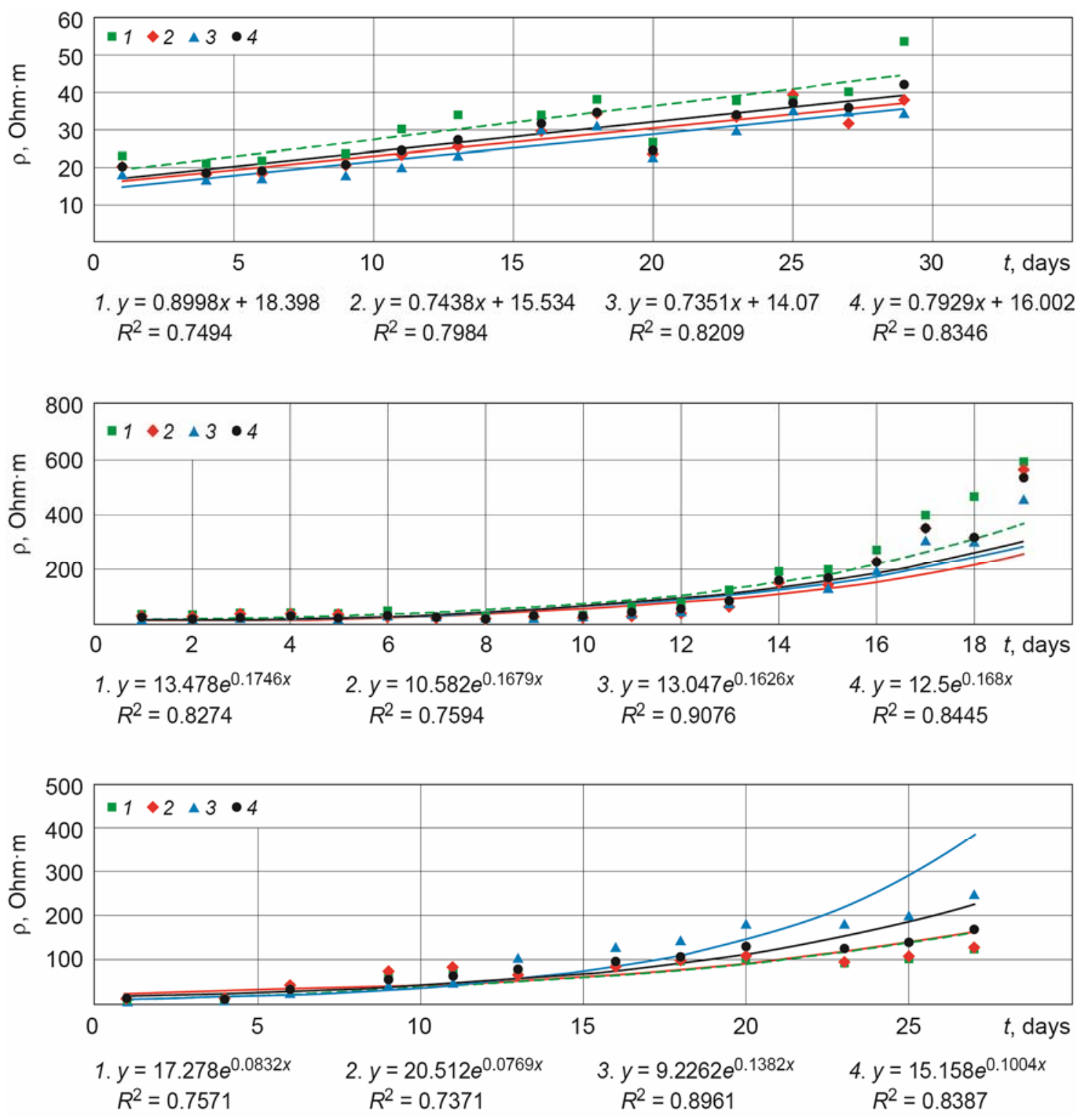

Fig. 6. Main tests in the Lexan box. Dependence of resistivity ( $\rho, \mathrm{Ohm} \cdot \mathrm{m})$ on time ( $t$, days) since the start of the measurement cycle when the sample dries for three soil conditions: uncompacted (above), with bamboo sticks (center), compacted with bamboo sticks (below) at a depth of $2 \mathrm{~cm}(1), 6.5 \mathrm{~cm}(2)$, and $13.5 \mathrm{~cm} \mathrm{(3)} \mathrm{and} \mathrm{an} \mathrm{average} \mathrm{value} \mathrm{between} \mathrm{them} \mathrm{(4).} \mathrm{Under} \mathrm{the} \mathrm{graphs} \mathrm{-} \mathrm{the} \mathrm{equations} \mathrm{of} \mathrm{the} \mathrm{ap-}$ proximating curves $y(x)$ for depth values $1-4$ with the corresponding coefficients of determination $R$

Рис. 6. Основные испытания в лексановом контейнере. Зависимость удельного сопротивления ( $\rho$, Ом'м) от времени $(t$, сут) с момента начала цикла измерений при высыхании образца для трех состояний почвы: неуплотненной (вверху), с бамбуковыми палочками (по центру), уплотненной с бамбуковыми палочками (внизу) на глубине 2 см (1), 6.5 см (2) и 13.5 см (3) и средним значением между ними (4). Под графиками - уравнения аппроксимирующих кривых $y(x)$ для значений глубины $1-4$ с соответствующими коэффициентами детерминации $R$

The three drying cycles have different duration, but a homogeneous and gradual behavior (Fig. 7). The influence of the presence of wooden elements, other conditions being equal, is also evident in the resistivity difference measurement, during the bamboo sticks insertion (Fig. 8). The results show a different behavior in terms of soil resistivity, at varying the presence of wooden elements, keeping constant humidity. 


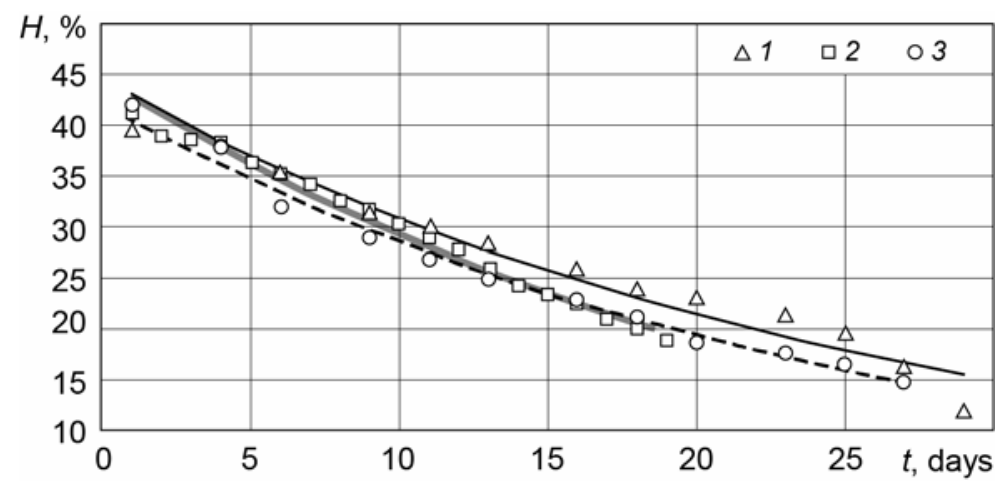

Fig. 7. Main tests in the Lexan box. Dependence of humidity $(H, \%)$ on time ( $t$, days) since the start of the measurement cycle when the sample dries for three soil conditions: uncompacted ( 1 , black line approximating curve described by the equation $y=44.446 e^{-0.036 x}$, determination coefficient $R^{2}=0.9283$, $p$-level of significance $p$-value $<2.2 \cdot 10^{-16}$ ); with bamboo sticks (2, gray line - approximating curve $y=45.027 e^{-0.043 x}, R^{2}=0.9852, p$-value $\left.=4.788 \cdot 10^{-8}\right)$; compacted (3, dashed line - approximating curve $y=42.225 e^{-0.039 x}, R^{2}=0.8394$, $p$-value $=1.521 \cdot 10^{-11}$ )

Рис. 7. Основные испытания в лексановом контейнере. Зависимость влажности $(H, \%)$ от времени $(t$, сут) с момента начала цикла измерений при высыхании образца для трех состояний почвы: неуплотненной ( 1 , черная линия - аппроксимирующая кривая, описываемая уравнением $y=44.446 e^{-0.036 x}$, коэффициент детерминации $R^{2}=0.9283$, $p$-уровень значимости $p$-value $<2.2 \cdot 10^{-16}$ ); с бамбуковыми палочками (2, серая линия - аппроксимирующая кривая $y=45.027 e^{-0.043 x}$, $R^{2}=0.9852$, $p$-value $\left.=4.788 \cdot 10^{-8}\right)$; уплотненной $(3$, штриховая линия - аппроксимирующая кривая $y=42.225 e^{-0.039 x}, R^{2}=0.8394$, $p$-value $=1.521 \cdot 10^{-11}$ )

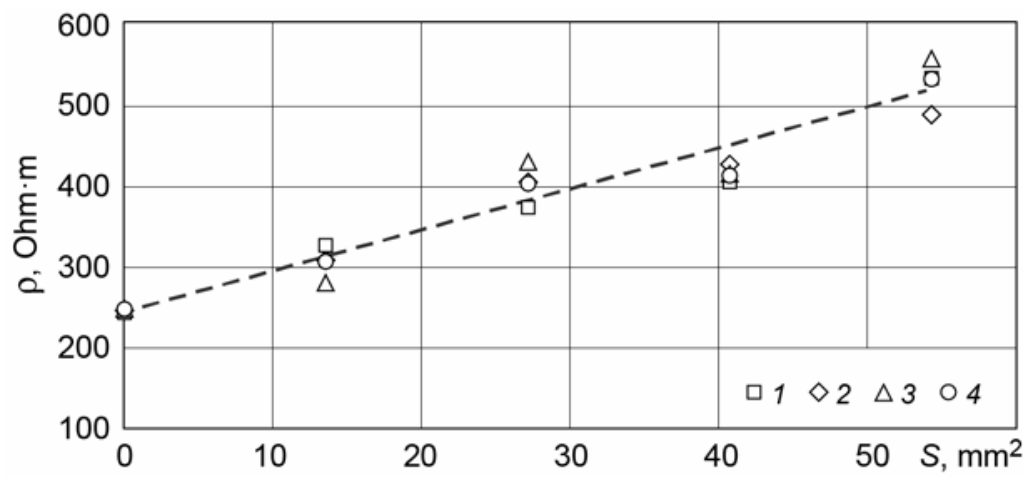

Fig. 8. Main tests in the Lexan box. Dependence of the resistivity $(\rho, \mathrm{Ohm} \cdot \mathrm{m})$, averaged at a depth of $2 \mathrm{~cm}(1), 6.5 \mathrm{~cm} \mathrm{(2),} 13 \mathrm{~cm} \mathrm{(3)} \mathrm{and} \mathrm{the} \mathrm{average} \mathrm{value} \mathrm{between} \mathrm{them} \mathrm{(4),} \mathrm{on} \mathrm{the} \mathrm{total} \mathrm{sectional} \mathrm{area} \mathrm{of}$ inserted bamboo sticks $\left(S, \mathrm{~mm}^{2}\right)$. Dashed line - approximating straight line described by the equation $y=4.9902 x+247.19$, determination coefficient $R^{2}=0.9542, p$-level of significance $p$-value $=0.004219$

Рис. 8. Основные испытания в лексановом контейнере. Зависимость удельного сопротивления ( $\rho$, Ом·м), усредненного на глубине 2 см (1), 6.5 см (2), 13 см (3) и средним между ними значением (4), от суммарной площади сечения вставленных бамбуковых палочек $\left(S\right.$, мм² $^{2}$. Штриховая линия - аппроксимирующая прямая, описываемая уравнением $y=4.9902 x+247.19$, коэффициент детерминации $R^{2}=0.9542, p$-уровень значимости $p$-value $=0.004219$

The resistivity trend is different for three tests, we find a linear progression for the "incompact without bamboo sticks" test, compared to the "with bamboo sticks" tests, which show potential trends, both in relation to humidity (see Fig. 5) and the trend over time (see Fig. 6). For the "incompact with bamboo sticks" test we have measurements that deviate 
from the trend curve, in particular the last measurements of the test. However, the determination coefficients remain high and show a significant relationship. The "compact with bamboo sticks" test shows an intermediate trend between the first and second test, with some difference regarding the variation between the electrodes at different depths. The measurements close to the bottom are larger than those at $2 \mathrm{~cm}$ and $6.5 \mathrm{~cm}$, probably due to compaction. However, the average values are well comparable with the other tests and also in this case the significance coefficients are good (see Fig. 5, 6).

\section{Discussion}

The first tests show an evident influence of the presence of roots in the variation of resistivity, depending on other conditions. Carried on the preliminary tests provide us with an overview of the soil behavior in terms of resistance, subjected to a different physical state (presence of water, degree of compaction). The variations between the different types of soil are mainly determined by the chemical differences of the investigated soil [Nassereddine, Rizk, Nasserddine, 2013]. The results obtained are in agreement with what was found by other authors. Authors in [Amato et al., 2008] found a good correlation between soil resistivity and the quantity of roots in the subsoil. Also in the work [Amato et al., 2010] we find similar findings on the results obtained, moreover the quantity of roots and the resistivity are directly proportional. This work shows comparable results with the work [Rossi et al., 2011], as regards also the type of soil (clayey). Authors in [Attia al Hagrey, 2007] also find comparable relationships. From this work, we can also demonstrate how the presence of wooden material causes a change in soil resistivity.

It is evident that the resistivity values, when there are simulated roots in the soil, belong to a different statistical population compared to the non-vegetated soil. When the soil is more compact, therefore with a density more similar to natural conditions, the exponential trend is more similar to the trend of the dry series, this is because the greater proximity of the soil particles (which determines a greater density) determines a greater electroconductivity, compared to conditions of greater porosity. The trend of the resistivity values with soil without simulated roots has a linear progression (note the value of the exponential coefficient, markedly closer to zero) compared to the exponential trends of the resistivity measurements carried out with the presence of simulated roots.

The drying rate, therefore the number of days necessary to obtain the same soil moisture, changes according to the other parameters. It appears that the rate is greater when the wooden elements are present [Rao et al., 2020], this is because the bamboo sticks bring greater evaporation of water and affect the water circulation processes in the soil [Robinson, Slater, Schäfer, 2012]. When the density increases, the chemical strength of the system changes, so the water finds many more obstacles to break the strength from the bonds with the soil particles. Wood is an organic structure, [Liese, 1985] characterized by a high porosity (lymph conducting vessels), in fact it is generally an insulating material (for example in construction). The root acts as an interruption in the network on which the electric current moves, reducing conductivity. The variation between vegetated and non-vegetated soil is irrelevant when the soil is in high relative humidity conditions. Among the parameters that can affect the measurement, which have not been investigated in depth, are the cracks created with the drying of the sample and the edge effect [Aizebeokhai, Olayinka, 2011], given the limited size of the test sample. We believe that the cracks formation, visible in Fig. 3, on the right, may have influenced the last resistivity measurements for the "Incompact with bamboo sticks" test.

The methodology has some limitations, the lack of a real physical characterization of the materials (soil, bamboo, water used) does not allow for a direct analysis. However, the 
procedure is repeated with the same process, the only differences are related to the conditioning factors, which have been modified in a specific and precise way.

This combination leads to a reduction of errors, or in any case a low impact of these errors. The identified errors that could influence the test concern the margin (and bottom) effect given the small size of the Lexan box, the interaction between the electrodes, the formation of soil agglomerates near the bamboo sticks. We believe that errors related to the process are offset or otherwise do not affect the study.

We believe that the stated objectives in this study are satisfied by the results, as we can determine a clear influence of the soil resistivity, due to the presence of wooden elements. This statement is also supported by other authors, for example in work [Cassiani et al., 2012] we see how the presence of plants modifies the resistivity of the soil, but this variation cannot be attributed only to the evapotranspiration processes carried out by the plants, through which we obtain less humidity and a consequent decrease in soil resistivity.

\section{Conclusion}

From the data obtained from the performed experiments, we can see that the roots influence the resistivity of the soil. The different physical structure of the wood leads to a modification of the local characteristics of the complex structure: vegetated soil. The soil resistivity increases, for the soils under analysis, when the "simulated" roots are present and when the soil humidity is less than $30 \%$. The roots can be considered "obstacles" to the current conduction, moreover they have a decisive role on the evaporation processes. In fact, they influence the soil humidity trend and consequently the conductivity variation. The study was carried out with a preliminary test, in order to understand the relationship between soil and roots in relation to resistivity. The goal of the work was achieved with satisfactory results, regarding the influence of the roots in the variation of soil resistivity values. This study must be considered a starting point for further investigations of the geoelectric sounding technique for analysis on the distribution of root systems. Future necessary developments concern the application to real cases with live plants and natural soil conditions. The introduction of new techniques, such as 3D analysis and VERS [Alekseev, Kostecki, Abakumov, 2017; Nemtsova, Zhurbin, Zlobina, 2019] and as the tests replication over time with a 4D approach [Mary et al., 2018], could give good results to detect the root system distribution of a tree, and monitor the roots development and their physiological conditions, through a time-lapse analysis.

\section{Acknowledgements}

The authors express gratitude to Andrea Dani, Giulio Fazzini, Alessandro Errico, Lorenzo Lorenzi, Daniele Meschini, Giulia Censini for cooperating.

\section{Conflict of interest}

The authors declare that they have no known competing financial interests or personal relationships that could have appeared to influence the work reported in this paper.

\section{References}

Aizebeokhai A.P., Olayinka A.I., Anomaly effects of orthogonal paired-arrays for 3D geoelectrical resistivity imaging, Environmental Earth Sciences, 2011, vol. 64, no. 8, pp. 2141-2149. DOI: 10.1007/s12665-011-1041-9 
Alekseev I., Kostecki J., Abakumov E., Vertical electrical resistivity sounding (VERS) of tundra and forest tundra soils of Yamal region, International Agrophysics, 2017, vol. 31, pp. 1-8. DOI: 10.1515/intag-2016-0037

Amato M., Basso B., Celano G., Bitella G., Morelli G., Rossi R., In situ detection of tree root distribution and biomass by multi-electrode resistivity imaging, Tree Physiology, 2008, vol. 28, no. 10, pp. 1441-1448. DOI: 10.1093/treephys/28.10.1441

Amato M., Rossi R., Bitella G., Lovelli S., Multielectrode geoelectrical tomography for the quantification of plant roots, Italian Journal of Agronomy, 2010, vol. 5, no. 3, pp. 257-263. DOI: 10.4081/ija.2010.257

Attia al Hagrey S., Geophysical imaging of root-zone, trunk, and moisture heterogeneity, J. Exp. Bot., 2007, vol. 58, pp. 839-854. DOI:10.1093/jxb/erl237

Batayneh A.T., Al-Diabat A.A., Application of a two-dimensional electrical tomography technique for investigating landslides along the Amman-Dead Sea highway, Jordan, Environmental Geology, 2002, vol. 42, no. 4, pp. 399-403. DOI: 10.1007/s00254-002-0543-x

Bischetti G.B., Chiaradia E.A., Epis T., Morlotti E., Root cohesion of forest species in the Italian Alps, Plant and Soil, 2009, vol. 324, no. 1, pp. 71-89. DOI: 10.1007/s11104-009-9941-0

Cassiani G., Ursino N., Deiana R., Vignoli G., Boaga J., Rossi M., Perri M.T., Blaschek M., Duttmann R., Meyer S., Ludwig R., Soddu A., Dietrich P., Werban U., Noninvasive Monitoring of Soil Static Characteristics and Dynamic States: A Case Study Highlighting Vegetation Effects on Agricultural Land, Vadose Zone Journal, 2012, vol. 11, no. 3, Article ID: vzj2011.0195. DOI: 10.2136/vzj2011.0195

Chirico G.B., Borga M., Tarolli P., Rigon R., Preti F., Role of Vegetation on Slope Stability under Transient Unsaturated Conditions, Procedia Environ. Sci., 2013, vol. 19, pp. 932-941. DOI: 10.1016/j.proenv.2013.06.103

Giambastiani Y., Preti F., Errico A., Sani L., On the tree stability: pulling tests and modelling to assess the root anchorage, Procedia Environ. Sci. Eng. Manag., 2017, vol. 4, no. 4, pp. 207-218.

González-Ollauri A., Mickovski S.B., Hydrological effect of vegetation against shallow landslides: a technical approach, Geotech. Eng. Infrastruct. Dev., 2015, vol. 2, pp. 1753-1758, DOI: 10.1680/ecsmge. 60678

Herman R., An introduction to electrical resistivity in geophysics, Am. J. Phys., 2001, vol. 69, pp. $943-$ 952. DOI: $10.1119 / 1.1378013$

Isaev V., Kotov P., Sergeev D., Technogenic Hazards of Russian North Railway, in Transportation Soil Engineering in Cold Regions, Singapore: Springer, 2020, vol. 1, pp. 311-320. DOI: 10.1007/ 978-981-15-0450-1_32

Kaznacheev P.A., Popov I.Y., Modin I.N., Zhostkov R.A., Application of Independent Finite Element Modeling for Estimating the Effect of Simplest Landforms on Results of Inversion of Electrical Resistivity Tomography Data (Example of a Trench with the Triangular Cross-Section), Seismic Instruments, 2020, vol. 56, no. 5, pp. 531-539. DOI: 10.3103/S0747923920050084

Kulikov V.A., Kaminsky A.E., Yakovlev A.G., Combined inversion of electric resistivity tomography and magnetotelluric sounding for solving tasks of ore geophysics, Geofizicheskie issledovaniya (Geophysical research), 2017, vol. 18, no. 3, pp. 27-44. [In Russian]. DOI: 10.21455/gr2017.3-3

Lebedeva L.S., Bazhin K.I., Khristoforov I.I., Abramov A.A., Pavlova N.A., Efremov V.S., Ogonerov V.V., Tarbeeva A.M., Fedorov M.P., Nesterova N.V., Makarieva O.M., Suprapermafrost subaerial taliks, central Yakutia, Shestakovka River basin, Earth's Cryosph., 2019, vol. 23, no. 1, pp. 40-50. DOI: 10.21782/KZ1560-7496-2019-140-50

Liese W., Anatomy and properties of bamboo, in Proceedings of the International Bamboo Workshop, 1985, pp. 196-208.

Mary B., Peruzzo L., Boaga J., Schmutz M., Wu Y., Hubbard S.S., Cassiani G., Small-scale characterization of vine plant root water uptake via 3-D electrical resistivity tomography and mise-à-lamasse method, Hydrol. Earth Syst. Sci., 2018, vol. 22, pp. 5427-5444. DOI: 10.5194/hess-22$5427-2018$

Morris W., Moreno E., Sagues A., Practical evaluation of resistivity of concrete in test cylinders using a Wenner array probe, Cement and Concrete Research, 1996, vol. 26, no. 4, pp. 551-556. 
Nassereddine M., Rizk J., Nasserddine G., Soil Resistivity Data Computations; Single and Two - Layer Soil Resistivity Structure and Its Implication on Earthing Design, International Scholarly and Scientific Research \& Innovation, 2013, vol. 7, no. 1, pp. 35-40. DOI: 10.1109/ciced.2018. 8592188

Nemtsova O., Zhurbin I., Zlobina A., Vector analysis of pole-pole array for determining the 3D boundary of object, Near Surface Geophysics, 2019, vol. 17, no. 5, pp. 563-575. DOI: 10.1002/nsg. 12065

Okpoli C., Sensitivity and Resolution Capacity of Electrode Configurations, Int. J. Geophys., 2013, Article ID: 608037, pp. 1-15.

Pozdnyakov A., Pozdnyakova L., Electrical fields and soil properties, in 17 World Congress of Soil Science, Symposium no. 53, Symposium A Quarterly Journal In Modern Foreign Literatures, 2002, paper no. 1558., pp. 1-11.

Preti F., Petrone A., Soil bio-engineering for watershed management and disaster mitigation in Ecuador: a short-term species suitability test, iForest - Biogeosciences and Forestry, 2013, vol. 6, no. 2, pp. 95-99. DOI: 10.3832/ifor0636-006

Rao S., Lesparre N., Orozco A.F., Wagner F., Javaux M., Imaging plant responses to water deficit using electrical resistivity tomography, Plant and Soil, 2020, vol. 454, pp. 261-281. DOI: 10.1007/ s11104-020-04653-7

Reynolds J.M., An Introduction to Applied and Environmental Geophysics, Wiley, 1997.

Robinson J.L., Slater L.D., Schäfer K.V.R., Evidence for spatial variability in hydraulic redistribution within an oak-pine forest from resistivity imaging, Journal of Hydrology, 2012, vol. 430-431, pp. 69-79. DOI: 10.1016/j.jhydrol.2012.02.002.

Rossi R., Amato M., Bitella G., Bochicchio R., Ferreira Gomes J.J., Lovelli S., Martorella E., Favale P., Electrical resistivity tomography as a non-destructive method for mapping root biomass in an orchard, European Journal of Soil Science, 2011, vol. 62, no. 2, pp. 206-215. DOI: 10.1111/j.1365-2389.2010.01329.x

Samouëlian A., Cousin I., Tabbagh A., Bruand A., Richard G., Electrical resistivity survey in soil science: A review, Soil Tillage Res., 2005, vol. 83, pp. 173-193. DOI: 10.1016/j.still.2004.10.004

Schwarz M., Cohen D., Or D., Root-soil mechanical interactions during pullout and failure of root bundles, Journal of Geophysical Research: Earth Surface, 2010, vol. 115, no. 4, pp. 1-19. DOI: 10.1029/2009JF001603

Simakov A., Vakulenko S., Politcina A., Ivanov P., Rusakov E., Marchenko M., Shustov N., Efficiency Evaluation of High-Resolution Seismic; Electrical Resistivity Tomography and Electromagnetic Surveys on Rivers, Based on Modelling Studies, in Engineering and Mining Geophysics. European Association of Geoscientists \& Engineers, 2020, vol. 2020, no. 1, pp. 1-12.

Skvortsova E.B., Shein E.V., Abrosimov K.N., Gerke K.M., Korost D.V., Romanenko K.A., Belokhin V.S., Dembovetskii A.V., Tomography in soil science, Byulleten Pochvennogo instituta im. V.V. Dokuchaeva, 2016, vol. 86, pp. 28-34. DOI: 10.35595/2414-9179-2020-4-26-131-146

Tiapkin O.K., Lozovyi A.L., Burlakova A.O., Pihulevskyi P.H., Geoinformation Support of Increase of Efficiency of Soil Cleaning from Petroleum Pollution, in 18th International Conference on Geoinformatics-Theoretical and Applied Aspects. European Association of Geoscientists \& Engineers, 2019, vol. 2019, no. 1, pp. 1-5.

Zenone T., Morelli G., Teobaldelli M., Fischanger F., Matteucci M., Sordini M., Armani A., Ferrè C., Chiti T., Seufert G., Preliminary use of ground-penetrating radar and electrical resistivity tomography to study tree roots in pine forests and poplar plantations, Functional Plant Biology, 2008, vol. 35 , no. 10 , pp. 1047-1058. DOI: 10.1071/FP08062

\section{About the authors}

GIAMBASTIANI Yamuna - CNR-IBE, Institute of Bioeconomy, National Research Council, via Madonna del Piano 10-50019 Sesto F.no, Florence, Italy; Bluebiloba Startup Innovativa SRL, Via C. Salutati 78-50126 Florence, Italy; FORTECH - DAGRI Joint Laboratory - Innovative technologies for 
the sustainable forestry management, Via di S. Bonaventura, Quaracchi, 13-50145 Florence, Italy. E-mail: giambastiani@lamma.toscana.it,info@bluebiloba.com

GUASTINI Enrico - DAGRI, Department of Science and Technology of Agriculture, Food, Environment and Forestry, University of Florence, Via di S. Bonaventura, Quaracchi, 13-50145 Florence, Italy. E-mail: guastini.e@gmail.com

PRETI Federico - DAGRI, Department of Science and Technology of Agriculture, Food, Environment and Forestry, University of Florence, Via di S. Bonaventura, Quaracchi, 13-50145 Florence, Italy. FORTECH - DAGRI Joint Laboratory - Innovative technologies for the sustainable forestry management, Via di S. Bonaventura, Quaracchi, 13-50145 Florence, Italy. E-mail: federico.preti@unifi.it

CENSINI Gianfranco - GEORISORSE ITALIA SAS, Via E. Fermi, 8I-53048 Sinalunga, Siena, Italy. E-mail: g.censini@georisorse.it

\title{
ЛАБОРАТОРНЫЕ ИССЛЕДОВАНИЯ ВАРИАЦИЙ УДЕЛЬНОГО СОПРОТИВЛЕНИЯ ПОЧВЫ В ЗАВИСИМОСТИ ОТ НАЛИЧИЯ КОРНЕЙ
}

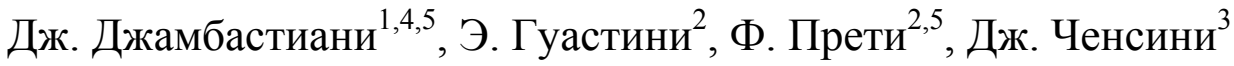 \\ ${ }^{1}$ CNR-IBE, Institute of Bioeconomy, National Research Council, Флоренция, Италия \\ ${ }^{2}$ DAGRI, Department of Science and Technology of Agriculture, Food, Environment and Forestry, Флорентий- \\ ский университет, Флоренция, Италия \\ ${ }^{3}$ GEORISORSE ITALIA SAS, Сиена, Италия \\ ${ }^{4}$ Bluebiloba Startup Innovativa SRL, Флорениия, Италия \\ ${ }^{5}$ FORTECH - DAGRI Joint Laboratory - Innovative technologies for the sustainable forestry management, \\ Флоренции, Италия \\ Автор для переписки: Дж. Джамбастиани (e-mail: giambastiani@lamma.toscana.it)
}

\begin{abstract}
Аннотация. Знание о распределении корневой системы растений играет важную роль в изучении устойчивости склонов, поскольку этот фактор определяет циркуляцию подземных вод и обеспечивает повышение таких геотехнических свойств почвы, как сила сцепления и угол трения. Опубликованные ранее исследования о применении in situ электротомографии демонстрируют, как наличие корней влияет на измеряемые значения удельного сопротивления почвы. Это подтверждает возможность проведения электротомографических изысканий, направленных на оценку плотности корней в почве косвенным и неинвазивным способом.

Настоящее исследование выполнялось в лабораторных условиях на искусственных образцах, и было направлено на поиск корреляции между вариациями удельного сопротивления и различными контролируемыми факторами, предположительно влияющими на результаты экспериментов, среди которых влажность, насыпная плотность, наличие инородных тел.

Образцы изготавливались из глинисто-суглинистой почвы, взятой из Каракки (Quaracchi, Флоренция, Италия), в экспериментальном еловом лесу (Picea abies), принадлежащем Scuola di Agraria Università degli Studi di Firenze. Указанное место впервые было выбрано для электротомографических исследований. Почва предварительно была высушена в лабораторной печи, просеяна через сито с размером ячеек 2 мм, после чего без уплотнения помещена в лексановый контейнер размерами $30 \times 20 \times 20$ см.

При проведении эксперимента двенадцать железных электродов помещались в образец по четыре в ряд на глубину 2, 6 и 13 см. Удельное сопротивление измерялось с помощью аппаратуры Syscal R2 по схеме Веннера. Присутствие корней имитировалось вставкой бамбуковых палочек, выбранных за простую геометрию и плотность, близкую к плотности корней. Максимальное количество палочек, используемых в ходе эксперимента, составило 48 штук. Измерения сопротивления проводились регулярно в течение длительного периода времени с контролем естественных колебаний влажности (испарения) и насыпной плотности (уплотнения).
\end{abstract}


Первые результаты показали увеличение удельного сопротивления с уменьшением средней влажности почвы и увеличением насыпной плотности. Наличие корней при равных условиях влечет за собой более высокие значения удельного сопротивления почвы, которое, на первый взгляд, экспоненциально зависит от влажности.

Ключевые слова: плотность корней, геофизика, водонасыщенность, косвенное обнаружение, электроразведка.

\section{Благодарности}

Авторы выражают благодарность Andrea Dani, Giulio Fazzini, Alessandro Errico, Lorenzo Lorenzi, Daniele Meschini, Giulia Censini за сотрудничество.

\section{Конфликт интересов}

Авторы заявляют, что у них нет известных конкурирующих финансовых интересов или личных отношений, которые могли бы повлиять на работу, описанную в настоящей статье.

\section{Литература}

Куликов В.А., Каминский А.Е., Яковлев А.Г. Совместная инверсия данных электротомографии и магнитотеллурических зондирований при решении рудных задач // Геофизические исследования. 2017. T. 18, № 3. C.27-44. DOI: 10.21455/gr2017.3-3

Aizebeokhai A.P., Olayinka A.I. Anomaly effects of orthogonal paired-arrays for 3D geoelectrical resistivity imaging // Environmental Earth Sciences. 2011. V. 64, N 8. P.2141-2149. DOI: 10.1007/s12665-011-1041-9

Alekseev I., Kostecki J., Abakumov E., Vertical electrical resistivity sounding (VERS) of tundra and forest tundra soils of Yamal region // International Agrophysics. 2017. V. 31. P.1-8. DOI: 10.1515/intag-2016-0037

Amato M., Basso B., Celano G., Bitella G., Morelli G., Rossi R. In situ detection of tree root distribution and biomass by multi-electrode resistivity imaging // Tree Physiology. 2008. V. 28, N 10. P.1441-1448. DOI: 10.1093/treephys/28.10.1441

Amato M., Rossi R., Bitella G., Lovelli S. Multielectrode geoelectrical tomography for the quantification of plant roots // Italian Journal of Agronomy. 2010. V. 5, N 3. P.257-263. DOI: 10.4081/ija.2010.257

Attia al Hagrey S. Geophysical imaging of root-zone, trunk, and moisture heterogeneity // J. Exp. Bot. 2007. V. 58. P.839-854. DOI:10.1093/jxb/er1237.

Batayneh A.T., Al-Diabat A.A. Application of a two-dimensional electrical tomography technique for investigating landslides along the Amman-Dead Sea highway, Jordan// Environmental Geology. 2002. V. 42 , N 4. P.399-403. DOI: 10.1007/s00254-002-0543-x

Bischetti G.B., Chiaradia E.A., Epis T., Morlotti E. Root cohesion of forest species in the Italian Alps // Plant and Soil. 2009. V. 324, N 1. P.71-89. DOI: 10.1007/s11104-009-9941-0

Cassiani G., Ursino N., Deiana R., Vignoli G., Boaga J., Rossi M., Perri M.T., Blaschek M., Duttmann R., Meyer S., Ludwig R., Soddu A., Dietrich P., Werban U. Noninvasive Monitoring of Soil Static Characteristics and Dynamic States: A Case Study Highlighting Vegetation Effects on Agricultural Land // Vadose Zone Journal. 2012. V. 11, N 3. Article ID: vzj2011.0195. DOI: 10.2136/vzj2011.0195

Chirico G.B., Borga M., Tarolli P., Rigon R., Preti F. Role of Vegetation on Slope Stability under Transient Unsaturated Conditions // Procedia Environ. Sci. 2013. V. 19. P.932-941. DOI: 10.1016/j.proenv. 2013.06.103

Giambastiani Y., Preti F., Errico A., Sani L. On the tree stability: pulling tests and modelling to assess the root anchorage // Procedia Environ. Sci. Eng. Manag. 2017. V. 4, N 4. P.207-218.

González-Ollauri A., Mickovski S.B. Hydrological effect of vegetation against shallow landslides: a technical approach // Geotech. Eng. Infrastruct. Dev. 2015. V. 2. P.1753-1758. DOI: 10.1680/ecsmge.60678

Herman R. An introduction to electrical resistivity in geophysics // Am. J. Phys. 2001. V. 69. P.943-952. DOI: $10.1119 / 1.1378013$

Isaev V., Kotov P., Sergeev D. Technogenic Hazards of Russian North Railway // Transportation Soil Engineering in Cold Regions. Singapore: Springer. 2020. V. 1. P.311-320. DOI: 10.1007/978-981-15-0450-1_32 
Kaznacheev P.A., Popov I.Y., Modin I.N., Zhostkov R.A. Application of Independent Finite Element Modeling for Estimating the Effect of Simplest Landforms on Results of Inversion of Electrical Resistivity Tomography Data (Example of a Trench with the Triangular Cross-Section) // Seismic Instruments. 2020. V. 56, N 5. P.531-539. DOI: 10.3103/S0747923920050084

Lebedeva L.S., Bazhin K.I., Khristoforov I.I., Abramov A.A., Pavlova N.A., Efremov V.S., Ogonerov V.V., Tarbeeva A.M., Fedorov M.P., Nesterova N.V., Makarieva O.M. Suprapermafrost subaerial taliks, central Yakutia, Shestakovka River basin // Earth's Cryosphys. 2019. V. 23, N 1. P.40-50. DOI: 10.21782/ KZ1560-7496-2019-140-50

Liese $W$. Anatomy and properties of bamboo // Proceedings of the International Bamboo Workshop. 1985. P.196-208.

Mary B., Peruzzo L., Boaga J., Schmutz M., Wu Y., Hubbard S.S., Cassiani G. Small-scale characterization of vine plant root water uptake via 3-D electrical resistivity tomography and mise-à-la-masse method // Hydrol. Earth Syst. Sci. 2018. V. 22. P.5427-5444. DOI: 10.5194/hess-22-5427-2018

Morris W., Moreno E., Sagues A. Practical evaluation of resistivity of concrete in test cylinders using a Wenner array probe // Cement and Concrete Research. 1996. V. 26, N 4. P.551-556.

Nassereddine M., Rizk J., Nasserddine G. Soil Resistivity Data Computations; Single and Two - Layer Soil Resistivity Structure and Its Implication on Earthing Design // International Scholarly and Scientific Research \& Innovation. 2013. V. 7, N 1. P.35-40. DOI: 10.1109/ciced.2018.8592188

Nemtsova O., Zhurbin I., Zlobina A. Vector analysis of pole-pole array for determining the 3D boundary of object // Near Surface Geophysics. 2019. V. 17, N 5. P.563-575. DOI: 10.1002/nsg.12065

Okpoli C. Sensitivity and Resolution Capacity of Electrode Configurations // Int. J. Geophys. 2013. Article ID: 608037. P.1-15.

Pozdnyakov A., Pozdnyakova L. Electrical fields and soil properties // 17 World Congress of Soil Science, Symposium no. 53, Symposium A Quarterly Journal In Modern Foreign Literatures. 2002. Paper no. 1558. P.1-11.

Preti F., Petrone A. Soil bio-engineering for watershed management and disaster mitigation in Ecuador: a shortterm species suitability test // iForest - Biogeosciences and Forestry. 2013. V. 6, N 2. P.95-99. DOI: 10.3832/ifor0636-006

Rao S., Lesparre N., Orozco A.F., Wagner F., Javaux M. Imaging plant responses to water deficit using electrical resistivity tomography // Plant and Soil. 2020. V. 454. P.261-281. DOI: 10.1007/s11104-020-04653-7

Reynolds J.M. An Introduction to Applied and Environmental Geophysics. Wiley, 1997.

Robinson J.L., Slater L.D., Schäfer K.V.R. Evidence for spatial variability in hydraulic redistribution within an oak-pine forest from resistivity imaging // Journal of Hydrology. 2012. V. 430/431. P.69-79. DOI: 10.1016/j.jhydrol.2012.02.002

Rossi R., Amato M., Bitella G., Bochicchio R., Ferreira Gomes J.J., Lovelli S., Martorella E., Favale P. Electrical resistivity tomography as a non-destructive method for mapping root biomass in an orchard // European Journal of Soil Science. 2011. V. 62, N 2. P.206-215. DOI: 10.1111/j.1365-2389.2010.01329.x

Samouëlian A., Cousin I., Tabbagh A., Bruand A., Richard G. Electrical resistivity survey in soil science: A review // Soil Tillage Res. 2005. V. 83. P.173-193. DOI: 10.1016/j.still.2004.10.004

Schwarz M., Cohen D., Or D. Root-soil mechanical interactions during pullout and failure of root bundles // Journal of Geophysical Research: Earth Surface. 2010. V. 115, N 4. P.1-19. DOI: 10.1029/2009JF001603

Simakov A., Vakulenko S., Politcina A., Ivanov P., Rusakov E., Marchenko M., Shustov N. Efficiency Evaluation of High-Resolution Seismic; Electrical Resistivity Tomography and Electromagnetic Surveys on Rivers, Based on Modelling Studies // Engineering and Mining Geophysics. European Association of Geoscientists \& Engineers. 2020. V. 2020, N 1. P.1-12.

Skvortsova E.B., Shein E.V., Abrosimov K.N., Gerke K.M., Korost D.V., Romanenko K.A., Belokhin V.S., Dembovetskii A.V. Tomography in soil science // Byulleten Pochvennogo instituta im. V.V. Dokuchaeva, 2016. V. 86. P.28-34. DOI: 10.35595/2414-9179-2020-4-26-131-146

Tiapkin O.K., Lozovyi A.L., Burlakova A.O., Pihulevskyi P.H. Geoinformation Support of Increase of Efficiency of Soil Cleaning from Petroleum Pollution // 18th International Conference on Geoinformatics-Theoretical and Applied Aspects. European Association of Geoscientists \& Engineers. 2019. V. 2019, N 1. P.1-5.

Zenone T., Morelli G., Teobaldelli M., Fischanger F., Matteucci M., Sordini M., Armani A., Ferrè C., Chiti T., Seufert $G$. Preliminary use of ground-penetrating radar and electrical resistivity tomography to study tree roots in pine forests and poplar plantations // Functional Plant Biology. 2008. V. 35, N 10. P.1047-1058. DOI: $10.1071 /$ FP08062 
Сведения об авторах

ДЖИАМБАСТИАНИ Джамуна - CNR-IBE, Institute of Bioeconomy, National Research Council, ул. Мадонны дель Пиано, 10-50019, Сесто-Фьорентино, Флоренция, Италия; Bluebiloba Startup Innovativa SRL, ул. К. Салютати, 78-50126, Флоренция, Италия; FORTECH - DAGRI Joint Laboratory - Innovative technologies for the sustainable forestry management, ул. С. ди Бонавентуры, Каракки, 13-50145, Флоренция, Италия. E-mail: giambastiani@lamma.toscana.it, info@bluebiloba.com

ГУАСТИНИ Энрико - DAGRI, Department of Science and Technology of Agriculture, Food, Environment and Forestry, Флорентийский университет, ул. С. ди Бонавентуры, Каракки, 13-50145, Флоренция, Италия. E-mail: guastini.e@gmail.com

ПРЕТИ Федерико - DAGRI, Department of Science and Technology of Agriculture, Food, Environment and Forestry, Флорентийский университет, ул. С. ди Бонавентуры, Каракки, 13-50145, Флоренция, Италия; FORTECH - DAGRI Joint Laboratory - Innovative technologies for the sustainable forestry management, ул. С. ди Бонавентуры, Каракки, 13-50145, Флоренция, Италия. E-mail: federico.preti@unifi.it

ЧЕНСИНИ Джанфранко - GEORISORSE ITALIA SAS, ул. Э. Ферми, 8I-53048, Синалунга, Сиена, Италия. E-mail: g.censini@georisorse.it 